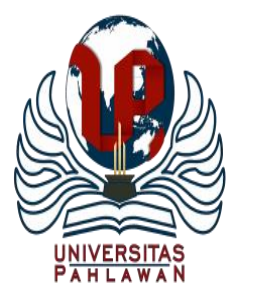

Jurnal Abdidas Volume 1 Nomor 5 Tahun 2020 Halaman 478 - 486

JURNAL ABDIDAS

http://abdidas.org/index.php/abdidas

\title{
Pemanfaatan Ekstrak Bunga Mawar Merah (Rosa hybrida) Asal Desa Bonto Majannang Kabupaten Bantaeng sebagai Indikator Formalin pada Ikan Asin
}

\author{
Sulfiani $^{1}$, Sukmawati ${ }^{2}$ \\ Universitas Megarezky, Sulawesi Selatan, Indonesia ${ }^{1,2}$ \\ E-mail : sulfianihasan80@gmail.com ${ }^{1} \underline{\text { sukmawatitlm@gmail.com }}^{2}$
}

\begin{abstract}
Abstrak
Banyaknya penggunaan pengawet bahan makanan yang seharusnya tidak diperuntukkan untuk bahan pangan seperti formalin menjadi keresahan bagi masyarakat. Penggunaan pengawet formalin pada umumnya digunakan pada bahan makanan sumber protein seperti pada ikan asin. Selama ini indikator yang digunakan untuk deteksi formalin yaitu menggunakan strip formaldehid dan larutan kalium permanganat yang dapat diperoleh di toko bahan kimia yang biaya cukup mahal. Salah satu alternatif lain untuk deteksi adanya formalin dapat menggunakan zat pewarna alami dari senyawa antosianin. Senyawa antosianin dapat diperoleh pada ekstrak bunga mawar merah. Di Desa Majannang Kabupaten Bantaeng hampir semua warga memiliki tanaman bunga mawar merah yang hanya dijadikan sebagai penghias taman. Untuk itu dengan kandungan yang terdapat pada bunga mawar merah dapat berfungsi sebagai zat pewarna alami antosianin yang dapat digunakan sebagai indikator deteksi formalin. Metode yang digunakan untuk pembuatan indikator formalin yaitu dengan cara ekstraksi dingin (maserasi) menggunakan larutan etanol $96 \%$ selama 3 hari untuk memperoleh ekstrak kental antosianin kemudian dibuat menjadi strip formalin menggunakan kertas saring whatman. Hasil yang diperoleh menggunakan indikator kertas formalin ekstrak bunga mawar merah yang diujikan ke sampel ikan asin yaitu indikator kertas yang telah dibuat berwarna merah muda dan jika di celupkan ke dalam sampel postif, indikator kertas tersebut warnaya tetap merah dan jika sampel negatif mengandung formalin maka indikator berubah warna ungu. Sehingga dapat disimpulkan bahwa indikator kertas ekstrak bunga mawar merah dapat dijadikan sebagai indikator formalin.
\end{abstract}

Kata kunci: bunga mawar, bantaeng, formalin

\section{Abstract}

The large number of uses of food preservatives that should not be intended for food, such as formaldehyde, is a public concern. The use of formaldehyde preservatives is generally used in protein source foods such as salted fish. So far, the indicators used for formalin detection are formaldehyde strips and potassium permanganate solution which can be obtained at chemical stores which are quite expensive. Another alternative to detect the presence of formaldehyde can use natural dyes from anthocyanin compounds. Anthocyanin compounds can be obtained in red rose flower extract. In Majannang Village, Bantaeng Regency, almost all residents have red roses which are only used as garden decorations. For this reason, the content contained in red roses can function as natural anthocyanin dyes that can be used as an indicator for formaldehyde detection. The method used for making formalin indicators was cold extraction (maceration) using 96\% ethanol solution for 3 days to obtain a thick anthocyanin extract then made into formalin strips using Whatman filter paper. The results obtained using the formalin paper indicator of red rose flower extract tested on the salted fish sample, namely the paper indicator that has been made pink and if immersed in the positive sample, the paper indicator remains red and if the negative sample contains formalin then the indicator turns purple. So it can be concluded that the red rose flower extract paper indicator can be used as an indicator of formalin.

Keywords: rose flower, bantaeng, formalin

Copyright (c) 2020 Sulfiani, Sukmawati

$\triangle$ Corresponding author

Address : Jalan Antang raya No. 43 Makassar

Email : sulfianihasan80@gmail.com

Phone : 081342740772

ISSN 2721-9224 (Media Cetak)

DOI : https://doi.org/10.31004/abdidas.v1i5.99

ISSN 2721 - 9216 (Media Online)

Jurnal Abdidas Vol 1 No 5 Tahun 2020 p-ISSN 2721-9224 e-ISSN 2721-9216 


\section{PENDAHULUAN}

Ikan merupakan salah satu sumber protein hewani yang banyak dikonsumsi masyarakat. Ikan cepat mengalami proses pembusukan, oleh karena itu sangat diperlukan tindakan yang tepat untuk mencegah pembusukan tersebut. Salah satunya dengan pembuatan ikan asin dengan melibatkan proses penggaraman. Pada proses pembuatan ikan asin, sering ditemukan adanya penambahan bahan kimia yang berbahaya yang dijadikan sebagai bahan pengawet.

Bahan pengawet merupakan salah satu jenis bahan tambahan makanan yang digunakan untuk mencegah atau menghambat fermentasi, pengasaman atau peruraian lain terhadap pangan yang disebabkan adanya mikroorganisme. Bahan pengawet yang diizinkan untuk makanan antara lain asam benzoate, Na-Benzoat, K-benzoat, asam Propionat, Asam Sorbat dan garamnya. Untuk bahan pengawet yang tidak diizinkan ditambahkan pada bahan pangan salah satunya adalah formalin (Menteri Kesehatan Republik Indonesia, 2012).

Formalin adalah larutan yang tidak berwarna dan baunya sangat menusuk. Didalam formalin terkandung sekitar $37 \%$ formaldehid dalam air. Formalin sering digunakan sebagai bahan desinfektan, bahan insektisida, bahan baku industri plastik dan digunakan juga pada berbagai macam industri seperti industri tekstil, farmasi, kosmetika serta digunakan untuk mengawetkan mayat.

Formalin dapat masuk kedalam tubuh dengan jalan inhalasi uap, kontak langsung dengan larutan yang mengandung formalin, atau dengan jalan memakan atau meminum bahan makanan yang mengandung formalin. Apabila formalin tercampur dalam makanan dengan dosis yang rendah dapat menyebabkan keracunan. Namun apabila termakan dalam dosis yang tinggi akan sangat membahayakan karena kandungan formalin yang tinggi akan menyebabkan formalin bereaksi secara kimia dengan hampir semua zat didalam sel sehingga menekan fungsi sel dan menyebabkan kematian sel. Selain itu kandungan formalin yang tinggi dalam tubuh juga menyebabkan iritasi lambung, alergi, bersifat karsinogenik (menyebabkan kanker) dan bersifat mutagen (menyebabkan perubahan fungsi sel dan jaringan) dan hanya dalam beberapa jam saja akan menyebabkan kejang-kejang, kencing darah, muntah darah bahkan dapat berakibat buruk pada organ tubuh seperti kerusakan hati dan ginjal (Singgih, 2013).

Berdasarkan hasil penelitian yang dilakukan oleh (Baihaqi Zakaria, Taty Sulastri, 2014) menyatakan 10 dari 14 sampel ikan asin katamba positif mengandung formalin dan penelitian yang dilakukan oleh (Fatimah et al., 2017) bahwa 12 sampel ikan asin mengandung formalin. Banyaknya ditemukan penyalahgunaan penggunaan formalin menyebabkan konsumen ragu untuk komsumsi ikan asin. Oleh karena itu, perlunya dilakukan pemeriksaan formalin pada sampel khususnya pada bahan makanan. Salah satu metode yang digunakan secara kualitatif untuk uji formalin yaitu menggunakan larutan kalium permanganat dan indikator (strip formaldehid) sebagai petunjuk bahwa sampel mengandung atau tidak formalin. 
Indikator merupakan petunjuk yang digunakan untuk analisis kualitatif yang dapat mengubah warna larutan dengan mudah, cepat dan dapat digunakan oleh siapa saja. Indikator formalin yang sering digunakan di laboratorium saat ini adalah indikator sintesis yang harganya mahal dan keberadaannya masih terbatas. Karena hal tesebut maka perlu dibuat indikator alternatif (indikator alami).

Indikator alami dapat dibuat dari berbagai tumbuhan berwarna, tetapi tidak semua tumbuhan berwarna dapat memberikan perubahan warna yang jelas pada suasana asam atau basa seperti bunga mawar memberikan warna merah pada suasana asam (Nuryanti et al., 2010). Bunga mawar memiliki potensi sebagai indikator alami karena mengandung senyawa pemberi warna pada tumbuhan yaitu senyawa antosianin.

Khususnya di Desa Bonto Majannang Kabupaten Bantaeng, bahwa hampir semua penduduk di desa tersebut memiliki tanaman bunga mawar merah yang dijadikan sebagai tanaman penghias taman. Mawar (Rosa hybrida) adalah salah satu sumber pigmen antosianin yang belum banyak dimanfaatkan. Mahkota bunga mawar juga diketahui mengandung pigmen antosianin yang tergolong flavanoid dan jenis antosianinnya adalah pelargonidin dan sianidin. Antosianin yang terdapat pada bunga mawar merah merupakan zat warna alami yang memberi warna merah pada bunga mawar dan mempunyai efek yang menguntungkan yaitu dapat digunakan untuk mendeteksi adanya formalin pada makanan yang mengandung protein. Berdasarkan hasil penelitian (Sinta Ratna Dewi, 2019) dapat mengidentifikasi formalin menggunakan ekstrak kulit buah naga (mengandung senyawa antosianin) pada sampel bakso, ikan asin dan udang rebon.

\section{METODE}

\section{Preparasi Sampel}

Dikeringkan sampel bunga mawar merah yang yang masih segar dan memiliki warna yang terang. Sampel yang terkumpul selanjutnya dibersihkan dengan aquades dan diambil pada bagian kelopak bunga mawar tersebut kemudian dikeringkan dengan cara dianginkan. Selanjutnya sampel dihaluskan, setelah halus sampel bunga mawar merah tersebut diekstraksi.

\section{Ekstraksi Sampel Menggunakan Maserasi}

Sampel bunga mawar merah yang telah dihaluskan ditimbang sebanyak 500 gram, ditambahkan $1000 \mathrm{ml}$ larutan etanol 96\% kemudian diasamkan dengan larutan asam klorida (HCl) $1 \%$ kemudian diaduk kurang lebih 30 menit setelah itu ditutup rapat ( $3 \times 24$ jam). Setiap $1 \times 24$ jam, disaring kemudian ditambahkan kembali dengan etanol 96\% sebanyak $500 \mathrm{ml}$. Dipisahkan antara etanol dengan ekstrak bunga mawar merah menggunakan rotary epavorator, Ditampung hasil ekstrak bunga mawar merah pada wadah yang bersih.

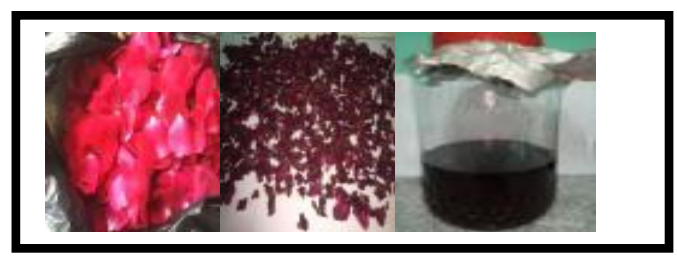

Gambar 1. Bunga Mawar Sebelum dan setelah ekstraksi 


\section{Deteksi Formalin menggunakan Strip Formaldehid pada Ikan Asin}

Ikan asin dihaluskan kemudian ditimbang sebanyak 2 gram dan ditambahkan aquades sebanyak $10 \mathrm{ml}$. Sampel disaring, kemudian dipipet sebanyak $5 \mathrm{ml}$ filtrat dan ditambahkan 10 tetes reagen contains sodium hidroxyde (Fo-1), setelah itu dihomogenkan dan dilakukan pengujian menggunakan strip test formaldehid. Diamati perubahan warna yang terjadi. Pembacaan hasil setelah 1 menit dengan mengamati perubahan warna yang terjadi pada strip test formaldehyde tersebut. Jika terjadi perubahan warna merah muda hingga warna ungu menandakan sampel ikan asin tersebut positif mengandung formalin.

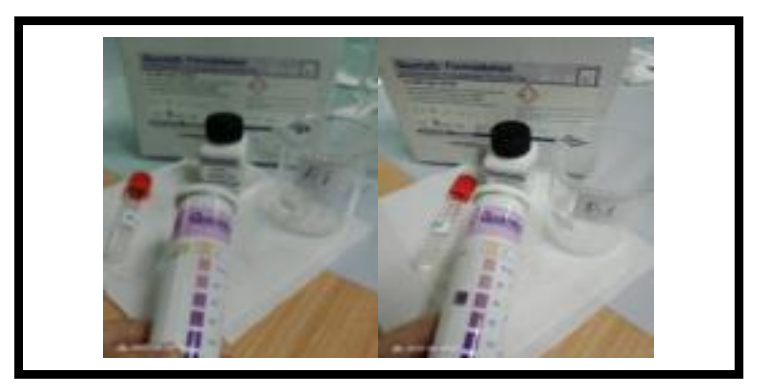

Gambar 2. Uji formalin menggunakan test formaldehid

\section{Proses Pembuatan Indikator Strip Formalin Ekstrak Bunga Mawar Merah}

Kertas saring digunting dengan ukuran 4,5 $\mathrm{cm} \times 6,5 \mathrm{~cm}$, dituang ekstrak bunga mawar merah ke dalam cawan petri, dicelupkan kertas saring dalam larutan indikator bunga mawar merah hingga tercelup seluruhnya dan biarkan lebih kurang 1 jam (lebih lama lebih baik agar warna menempel sempurna pada kertas saring), kemudian diangkat kertas saring tersebut dan letakkan di atas wadah atau tempat bersih, dibiarkan hingga kering. Setelah kering, warna kertas saring berubah menjadi kemerahan. Potong kertas saring yang telah kering dengan ukuran $1 \mathrm{x}$ $4,5 \mathrm{~cm}$. Kertas inilah yang disebut indkator kertas formalin ekstrak bunga mawar merah.

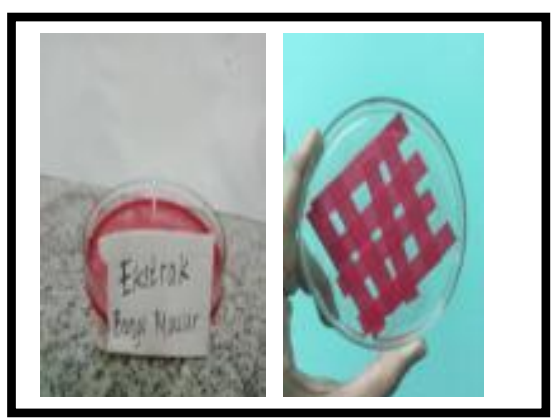

Gambar 3. Indikator strip formalin ekstrak bunga warna merah

\section{Penyiapan Kontrol Positif Dan Kontrol Negatif}

Sampel yang telah diuji menggunakan strip formaldehid yang dinyatakan negatif dijadikan sebagai kontrol negatif dan sampel yang negatif diberi penambahan formalin $1 \%$ sebagai kontrol positif yang sebelumnya telah di uji menggunakan strip formaldehid. Menyiapkan 2 tabung reaksi: tabung 1 berisi larutan sampel tanpa formalin dan tabung 2 berisi larutan sampel menggunakan formalin diuji menggunakan indikator kertas ekstrak bunga mawar. Hasil yang diperoleh dari indikator kertas ekstrak bunga mawar merah hasilnya sama dengan dengan menggunakan strip formaldehid.

\section{Uji formalin pada sampel ikan asin mengunakan indikator strip formalin ekstrak bunga mawar merah}

Menyiapkan tabung reaksi : tabung berisi larutan sampel diuji menggunakan indikator kertas ekstrak bunga mawar. Hasil yang diperoleh 
disesuaikan dengan kontrol, jika hasilnya warnanya sama dengan kontrol negatif maka sampel negatif mengandung formalin dan begitu sebaliknya.

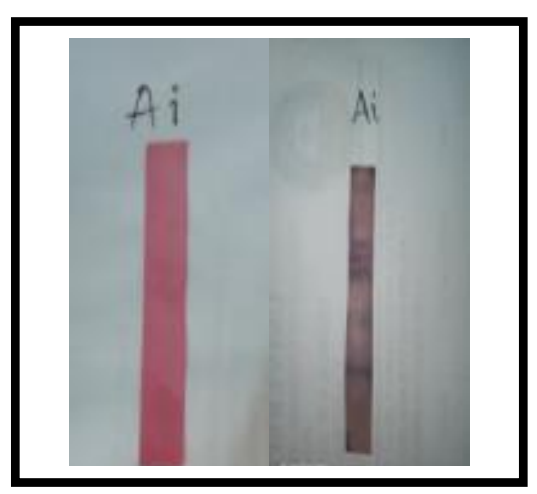

Gambar 5. Indikator Strip Ekstak Bunga mawar merah ; warna merah muda (positif) dan warna ungu (negatif)

\section{HASIL DAN PEMBAHASAN}

\section{Uji Kualitatif Formalin pada Ikan Asin Menggunakan Strip Formaldehid Test}

Tabel 1. Hasil Pemeriksaan Formalin pada Ikan Asin Menggunakan Strip Formaldehid

\begin{tabular}{|c|c|c|c|}
\hline No & $\begin{array}{c}\text { Kode } \\
\text { Sampel }\end{array}$ & Hasil Pengamatan & $\begin{array}{c}\text { Hasil } \\
\text { Analisa }\end{array}$ \\
\hline 1 & Kontrol + & Strip Warna Ungu & $\begin{array}{c}+ \\
200 \mathrm{mg} / 1\end{array}$ \\
\hline 2 & $\begin{array}{c}\text { Kontrol } \\
-\end{array}$ & Strip warna kuning & - \\
\hline 3 & $\mathrm{Ai}$ & Strip warna kuning & - \\
\hline 4 & $\mathrm{Bi}$ & Strip Warna Ungu & $\begin{array}{c}+ \\
40 \mathrm{mg} / 1\end{array}$ \\
\hline 5 & $\mathrm{Ci}$ & Strip warna kuning & - \\
\hline 6 & $\mathrm{Di}$ & Strip Warna Ungu & $\begin{array}{c}+ \\
20 \mathrm{mg} / 1\end{array}$ \\
\hline 7. & $\mathrm{Ei}$ & Strip Warna Ungu & $\begin{array}{c}+ \\
10 \mathrm{mg} / 1\end{array}$ \\
\hline 8 & $\mathrm{Fi}$ & Strip warna kuning & - \\
\hline 9. & $\mathrm{Gi}$ & Strip Warna Ungu & $\begin{array}{c}+ \\
10 \mathrm{mg} / 1\end{array}$ \\
\hline
\end{tabular}

Uji formalin pada ikan asin menggunakan strip formaldehid test, dimana sampel ikan asin yang digerus sampai halus kemudian ditambahkan aquades untuk mendapatkan filtratnya. Filtrat yang diperoleh ditambahkan dengan reagen contains sodium hidroxyde (Fo-1). Diamati perubahan warna yang terjadi pada strip di botol strip formaldehid test.

Berdasarkan data pada tabel 1 , dapat dilihat pada kontrol positif yang dimana terjadi perubahan warna strip dari berwarna kuning menjadi berwarna ungu pekat dengan kadar formalin tertinggi yaitu 200 mg/l. Pada sampel Ai, Ci dan Fi tidak terjadi perubahan warna strip awal warna kuning yang menandakan sampel tersebut tidak mengandung formalin $0 \mathrm{mg} / \mathrm{l}$ atau negatif formalin. Pada sampel Bi terjadi perubahan warna strip dari berwarna kuning menjadi berwarna ungu dengan kadar formalin $40 \mathrm{mg} / \mathrm{l}$. Kemudian pada sampel Di terjadi perubahan warna strip dari berwarna kuning menjadi berwarna merah muda tua dengan kadar formalin $20 \mathrm{mg} / \mathrm{l}$. Pada sampel Ei dan Fi terjadi perubahan warna strip dari berwarna kuning menjadi berwarna merah muda dengan kadar formalin $10 \mathrm{mg} / \mathrm{l}$.

\section{Uji Kualitatif Formalin pada Ikan Asin Menggunakan Indikator Kertas Ekstrak Bunga Mawar Merah}

Ekstrak bunga mawar merah akan diolah menjadi indikator dengan cara merendam kertas saring ke dalam ekstrak bunga mawar merah selama 1 jam dan dikeringkan. Indikator kertas ekstrak bunga mawar merah selanjutnya diuji coba pada ikan asin dan diperoleh data hasil pemeriksaan sebagai berikut:

Tabel. 2 Data hasil pemeriksaan formalin pada ikan asin menggunakan kertas tumerik bunga mawar merah

\begin{tabular}{|l|c|c|c|}
\hline No & Kode & Hasil Pengamatan & Hasil \\
\hline
\end{tabular}



Bantaeng sebagai Indikator Formalin pada Ikan Asin - Sulfiani, Sukmawati DOI : https://doi.org/10.31004/abdidas.v1i5.99

\begin{tabular}{|c|c|c|c|}
\hline & Sampel & Uji \\
\hline 1 & Kontrol + & $\begin{array}{c}\text { Indikator ekstrak } \\
\text { warna merah muda }\end{array}$ & + \\
\hline 2 & Kontrol - & $\begin{array}{c}\text { Indikator ekstrak } \\
\text { warna ungu }\end{array}$ & - \\
\hline 3 & $\mathrm{Ai}$ & $\begin{array}{c}\text { Indikator ekstrak } \\
\text { warna ungu }\end{array}$ & - \\
\hline 4 & $\mathrm{Bi}$ & $\begin{array}{c}\text { Indikator ekstrak } \\
\text { warna merah muda }\end{array}$ & + \\
\hline 5 & $\mathrm{Ci}$ & $\begin{array}{c}\text { Indikator ekstrak } \\
\text { warna ungu }\end{array}$ & - \\
\hline 6 & $\mathrm{Di}$ & $\begin{array}{c}\text { Indikator ekstrak } \\
\text { warna merah muda }\end{array}$ & + \\
\hline 7. & $\mathrm{Ei}$ & $\begin{array}{c}\text { Indikator ekstrak } \\
\text { warna merah muda }\end{array}$ & + \\
\hline 8 & $\mathrm{Fi}$ & $\begin{array}{c}\text { Indikator ekstrak } \\
\text { warna mersh muda }\end{array}$ & - \\
\hline 9 & $\mathrm{Fi}$ & $\begin{array}{c}\text { Indikator ekstrak } \\
\text { warna ungu }\end{array}$ & + \\
\hline
\end{tabular}

Berdasarkan data pada tabel 2 pada kontrol positif tidak terjadi perubahan warna awal merah muda. Pada kontrol negatif terjadi perubahan warna awal merah muda menjadi berwarna ungu. Kemudian pada tujuh sampel ikan asin yang diteliti, terdapat tiga sampel ikan asin yang negatif tidak mengandung formalin yaitu sampel $\mathrm{Ai}, \mathrm{Ci}$, dan Fi. Hal ini di tandai dengan terjadinya perubahan warna pada kertas tumerik bunga mawar merah dari merah muda menjadi berwarna ungu. Pada sampel ikan asin $\mathrm{Bi}, \mathrm{Di}, \mathrm{Ei}$ dan Gi mengandung formalin.Hal ini ditandai dengan tidak terjadinya perubahan warna pada kertas tumerik dari warna awal merah muda.

\section{Pembahasan}

Untuk melihat pemanfaatan ekstrak bunga mawar merah (Rosa hybrida) yaitu untuk mendeteksi adanya formalin pada ikan asin. Tahap awal dari penelitian ini adalah pembuatan ekstrak bunga mawar merah yang dilakukan dengan menggunakan metode meserasi. Maserasi merupakan suatu metode ekstraksi yang sangat sederhana yang dilakukan dengan cara merendam. Maserasi adalah salah satu metode ekstraksi sistem tanpa pemanasan atau yang dikenal dengan istilah ekstraksi dingin. Metode maserasi dipilih dalam penelitian ini disebabkan karena senyawa antosianin yang ingin diperoleh dari bunga mawar merah merupakan senyawa yang tidak stabil terhadap pemanasan dalam jangka waktu yang lama.

Proses maserasi dilakukan dengan menggunakan pelarut etanol diasamkan dengan larutan asam klorida $(\mathrm{HCl})$, pelarut ini dipilih karena larutan etanol bersifat universal yang dapat menarik banyak senyawa kimia, kemudian tidak beracun dan bersifat netral. Larutan asam klorida ( $\mathrm{HCl})$ dalam etanol akan mendenaturasi membran sel tanaman kemudian melarutkan pigmen antosianin keluar dari sel.

Proses maserasi dilakukan selama 3x24 jam dimana tujuannya yaitu untuk memberikan kesempatan kepada pelarut agar dapat menarik senyawa-senyawa aktif yang terdapat dalam bunga mawar merah secara maksimal. Setelah diperoleh hasil filtrasi maserasi bunga mawar merah, maka dilanjutkan dengan proses penguapan dengan menggunakan alat rotary evaporator yang bertujuan untuk memisahkan antara pelarut etanol yang digunakan dengan hasil ekstrak bunga mawar merah sesungguhnya, sehingga larutan yang diperoleh akan semakin pekat disebabkan karena di dalam larutan tersebut hanya mengandung senyawa-senyawa aktif yang terdapat didalam bunga mawar merah. Proses pengambilan sampel ikan asin dilakukan pada 7 titik penjual ikan asin 
dan diberi label kode sampel yaitu $\mathrm{Ai}, \mathrm{Bi}, \mathrm{Ci}, \mathrm{Di}$, Ei, Fi, dan Gi.

Metode strip test formaldehid, dimana tujuan dari kontrol ini yaitu sebagai petunjuk atau acuan hasil pemeriksaan yang nantinya dicocokkan dengan hasil pemeriksaan terhadap tujuh sampel ikan asin menggunakan indikator kertas bunga mawar merah. Pemeriksaan kontrol metode semikuantitatif dengan menggunakan strip test formaldehid dilakukan dengan cara mereaksikan antara sampel dengan reagen contains sodium hidroxyde (Fo-1) dimana prinsip kerja dari metode ini yaitu dengan pembentukan senyawa kompleks berwarna merah ungu dari reaksi antara formaldehid dan 4 amino-3-hidrazino-5 mercapto1,2,4-Triazole yang terkandung di dalam reagen contains sodium hidroxyde (Fo-1) tersebut. Fungsi dari penambahan reagen contains sodium hidroxyde (Fo-1) yaitu untuk bereaksi dengan kandungan formaldehid yang terdapat pada sampel yang dianalisa sehingga membentuk senyawa kompleks berwarna. Setelah dilakukan pencampuran dari bahan-bahan tersebut, maka dicelupkan strip test formaldehid sampai terendam seluruh indikator kertas latex parameternya. Kertas latex digunakan sebagai indikator untuk menentukan ada tidaknya kandungan formalin pada sampel berdasarkan dengan tingkatan konsentrasi formalin dalam sampel yang dianalisa.

Proses interpretasi hasil dari uji formalin menggunakan strip test formaldehid ini yaitu dengan cara mengamati perubahan warna yang terjadi pada kertas latex indikator yang tertempel pada strip test formaldehid yang nantinya dibandingkan dengan standar interpretasi hasil yang terdapat pada botol strip test formaldehid tersebut. Nilai positif dari uji menggunakan strip test ini yaitu dengan terjadinya perubahan warna awal kertas latex dari strip test formaldehid yang berwarna kuning dengan konsentrasi formalin didalamnya yaitu $0 \mathrm{mg} / \mathrm{l}$ (negatif), berwarna merah muda dengan konsentrasi formalin di dalamnya yaitu $10 \mathrm{mg} / \mathrm{l}$, berwarna merah muda tua dengan konsentrasi formalin didalamnya yaitu $20 \mathrm{mg} / \mathrm{l}$, berwarna merah muda keunguan dengan konsentrasi formalin di dalamnya yaitu $40 \mathrm{mg} / \mathrm{l}$, berwarna ungu dengan konsentrasi formalin di dalamnya yaitu $60 \mathrm{mg} / \mathrm{l}$, berwarna ungu pekat dengan konsentrasi formalin didalamnya yaitu 100 $\mathrm{mg} / \mathrm{l}$.

Hasil pemeriksaan terhadap tujuh sampel ikan asin menggunakan metode strip test formaldehid, diperoleh hasil seperti yang terdapat pada tabel 1. Hasil dari ke tujuh sampel yang diuji, terdapat 3 sampel ikan asin memberikan hasil negatif yaitu pada sampel $\mathrm{Ai}, \mathrm{Ci}$ dan Fi, yang ditandai dengan tidak terjadinya perubahan warna yaitu kuning pada strip test formaldehid tersebut. Pada Ei dan Gi memberikan hasil positif $10 \mathrm{mg} / \mathrm{l}$ yang ditandai dengan perubahan warna pada strip test dari warna kuning menjadi berwarna merah muda. Pada sampel Bi memberikan hasil positif 30 $\mathrm{mg} / \mathrm{l}$ yang ditandai dengan perubahan warna pada strip test dari warna kuning menjadi berwarna ungu. Dan pada sampel di memberikan hasil positif $20 \mathrm{mg} / \mathrm{l}$ yang ditandai dengan perubahan warna pada strip test dari warna kuning menjadi berwarna merah muda tua.

Setelah dilakukan uji kontrol semikuantitatif menggunakan metode strip test formaldehid maka 
dilanjutkan dengan pemeriksaan formalin pada ikan asin menggunakan indikator kertas ekstrak bunga mawar merah. Interpretasi hasil dari metode ini yaitu dengan melihat perubahan warna.

Secara umum pada bunga mawar merah terdapat kadar kandungan antosianin yang tinggi. Dimana antosianin sangatlah dipengaruhi stabilitasnya oleh keberadaan protein sehingga protein dapat bereaksi dengan antosianin membentuk endapan atau gelatin dan dapat menyebabkan zat warna dari antosianin hilang.

Ikan asin merupakan makanan yang diawetkan dengan menggunakan garam. Ikan asin memiliki kandungan protein yang sangat tinggi, akan tetapi ikan asin sering diawetkan dengan menggunakan zat-zat aditif yang salah satunya berguna untuk memperpanjang masa simpan bahan pangan, contohnya formalin. Ikan asin yang mengandung protein diawetkan dengan menggunakan formalin maka gugus aldehid akan mengikat gugus amina sehingga menyebabkan degradasi protein dan menimbulkan hilangnya kandungan protein di dalam ikan asin tersebut. Kemudian bila direaksikan menggunakan kandungan antosianin tinggi maka warna akan tetap stabil disebabkan karena tidak terdapatnya kandungan protein dalam ikan asin yang mengganggu stabilitas dari antosianin.

Hasil pemeriksaan ikan asin dengan indikator kertas bunga mawar merah pada 7 sampel yang di uji coba seperti yang terdapat pada tabel 2. Dimana terdapat 4 sampel ikan asin yang memberikan hasil positif yaitu pada sampel Bi, Di, $\mathrm{Ei}$, dan $\mathrm{Gi}$ yang ditandai dengan warna merah muda pada indikator kertas ekstrak bunga mawar merah yang tetap stabil dan tidak mengalami perubahan warna. Hal ini disebabkan karena terdapatnya gugus aldehid dalam larutan formalin yang mengikat kandungan protein didalam ikan asin sehingga terjadi degradasi protein dan menyebabkan hilangnya kandungan protein di dalam ikan asin. Sehingga antosianin yang terdapat pada indikator kertas tersebut tidak mengalami perubahan warna (Nuhman \& Wilujeng, 2017) dan terdapat 3 sampel yang negatif tidak mengandung formalin yaitu sampel Ai, Ci dan Fi yang ditandai dengan berubahnya warna merah muda dari indikator kertas bunga mawar merah. Hal ini disebabkan karena tidak terdapatnya gugus aldehid dari larutan formalin yang mengikat protein dalam ikan asin, sehingga kandungan protein dalam ikan asin bereaksi dengan antosian pada indikator kertas ekstrak bunga mawar merah yang menyebabkan hilangnya warna merah muda dari antosianin.

Hasil yang diperoleh pada pemeriksaan menggunakan indikator kertas ekstrak bunga mawar merah sama dengan hasil dari uji menggunakan strip test formaldehid.

\section{SIMPULAN}

Indikator kertas ekstrak bunga mawar merah dengan pelarut etanol yang diasamkan dengan larutan $\mathrm{HCl}$ dapat dijadikan sebagai indikator formalin pada makanan, salah satunya yaitu ikan asin yang telah diuji coba pada penelitian ini dengan melihat perubahan warna yang terjadi. Adapun hasil pemeriksaan formalin yang dilakukan pada 7 sampel ikan asin menggunakan indikator kertas ekstrak bunga mawar merah 
memberikan hasil yang sama dengan hasil pemeriksaan menggunakan strip test formaldehid. Hasil yang diperoleh yaitu 4 sampel ikan asin positif mengandung formalin yaitu pada sampel Bi, Di, Ei, dan Gi, sedangkan 3 sampel ikan asin negatif tidak mengandung formalin yaitu pada sampel Ai, Ci dan Fi.

\section{DAFTAR PUSTAKA}

Baihaqi Zakaria, Taty Sulastri, S. (2014). Analisis Kandungan Formalin pada Ikan Asin Katamba ( Lethrinus lentjan ) yang Beredar Di Kota Makassar. Jurnal Chemical, 15(2), 16-23.

Fatimah, S., Astuti, D. W., \& Awalia, N. H. (2017). Analisis Formalin Pada Ikan Asin Di Pasar Giwangan Dan Pasar Beringharjo Yogyakarta. Analit: Analytical and Environmental Chemistry, 2(01), 22-28.

Hastuti, R. T., \& Rusita, Y. D. (2020). Deteksi Sederhana Boraks dan Formalin pada Makanan Jajanan Anak dengan Bunga Terompet Ungu (Ruellia Tuberosa). Jurnalempathy.Com, 1(1), 85-95. https://doi.org/10.37341/jurnalempathy.v1i1. 14

Kandungan, U. J. I., Pada, F., Asin, I., \& Pasar, D. I. (2016). Uji Kandungan Formalin Pada Ikan Asin Di Pasar Km 5 Palembang. Bioilmi: Jurnal Pendidikan, 2(2), 121-128. https://doi.org/10.19109/bioilmi.v2i2.1136

Menteri Kesehatan Republik Indonesia. (2012). Bahan Tambahan Pangan.

Nasution, A. S., Ervina, A., \& Supriatna, S. (2019). Untuk Identifikasi Formalin Pada Tahu Dengan Simple. 1(2), 82-86.

Nuhman, \& Wilujeng, A. E. (2017). Pemanfaatan Extrak Antosianin dari Bahan Alam untuk Identifikasi Formalin pada Tahu Putih. Jurnal Sains, 7(14), 8-15.

Nuryanti, S., Matsjeh, S., Anwar, C., \& Raharjo, T. J. (2010). INDIKATOR TITRASI ASAMBASA DARI EKSTRAK BUNGA SEPATU
(Hibiscus rosa sinensis L). Agritech, 30(3), 178-183.

Singgih, H. (2013). Uji Kandungan Formalin Pada Ikan Asin Menggunakan sensor Warna dengan Bantuan FMR (Foemlain Main Reagent). Jurnal Eltek, 11, 55-70.

Sinta Ratna Dewi. (2019). Identifikasi Formalin Pada makanan Menggunakan Ekstrak Buah Naga. Jurnal Nasiona Ilmu Kesehatan (JNIK), 2(Volume 2, Edisi I 2019), 45-51.

Yuliantini, A. (2019). Deteksi Formalin Dalam Makanan Dengan Indikator Alami Dari Ekstrak Bunga Telang (Clitoria Ternatea L.). Journal of Pharmacopolium, 1(3), 107-113. https://doi.org/10.36465/jop.v1i3.426 